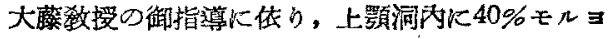

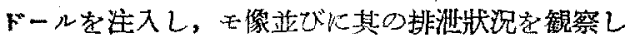

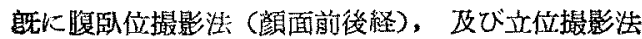
の成續老報告し太，正常上颚洞で不完全像星し て1週間內k完全排㴹されたのK病的上颚洞では完

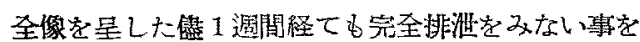
述一゙た・而して正常上颛洞にのみみられる不完全像 のぼやけた部分 (verschleierte Schatten) は洞粘 膜陷毛運動陰影像である慗を指摘した。

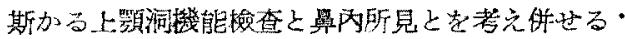
時，副宜腔资に対する極めて正確な診断浩であると 確信する。

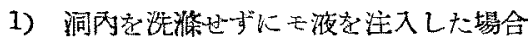

(1)住入直後 (又注1日後, 2 日後) のモ像方腹卧 位撮影法 (又的立位) に於て不完全像を是し更に 1 週間後のモ像が完全排㴹されていたならば正常上顎 洞.

(听注入直後（又的1日後，2日後）のモ像力腹卧 位撮影法 (及恃立位) に於で完圣像老呈し，更に1 週間後にも完全排泟されなければ病的上颚洞と見做 して良い。

2) 洞內洗源後モ液学注入した場合.

注入 2 日後 (又は 1 日後)の玉像が腹卧位撮影法

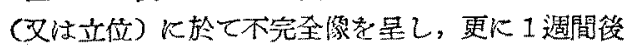
のモ像が完全排湛されていなならば正常であり完全 排澌されなければ病的上颚洞と見做してよい。

\section{4. 艒中隔彎曲症に関するし線学的}

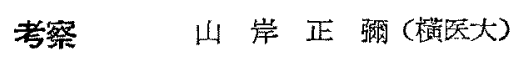

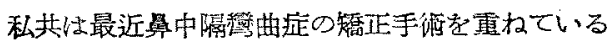
中に，單なる矯正沺のみで，之と密接な関係にある

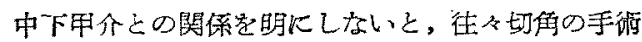

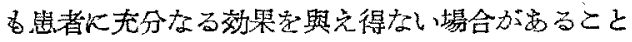
に氧附いた。

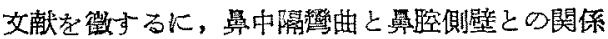

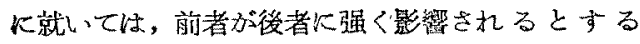
Zuckerkandl の說と，影響され好とするPassow氏 等の說之が女り，両者に就いては，夫及篮否両論相 牛し，現在比至るむ窮明せられていないのを知つた。

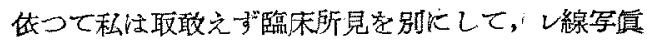

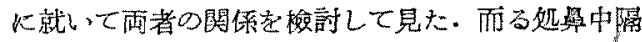

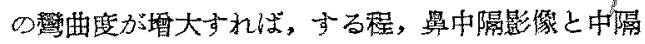

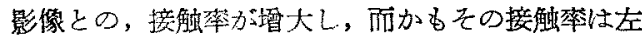

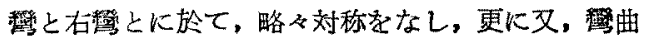

度が習大すれば，中隔影像之片側中甲介影線の接触

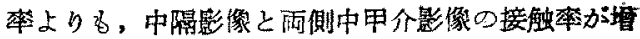

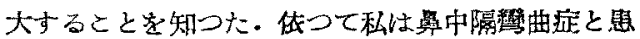
䶼側壁との関係炕就いては，Zuckerkandl の說が 正当なのではないかと考えるるのである。

\section{5. 前額洞レントゲン学知見補遺}

（続報）北村武 石浦純一（千大）

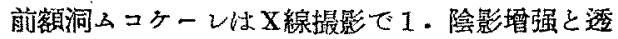
明化の一洞內の不规則湦在, 2 , 其等各部の正常 洞上り粗な感， 3 。洞陰影之周辺陰影々の不鮮銳な

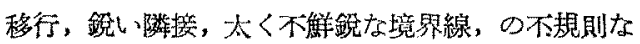
混在，4.骨壁の移動, 不均衡, 郚影消失, 線中断 の榙特徽定示しそれに伎り匙断を附し得るが，洞の 狀態の詳細な判断には洞案刺, モルヨドール注入が

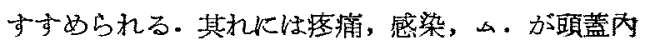
儿破れる危澰が要り，又內签全部をモ。で置換出來 ず，モ。は內容中に坛散世好が，吾々性上行性及下

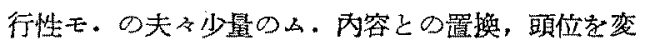
換しての数回のX撮影で洞の全貌を知り得た. 頭位 変換の際モ.が洞の上或は下部に移動して其部の狀 態を示す事る，又壁に附着して移動せずモ。の主塊 そ離九た部の狀態を示す事も声る・此の方法で知り 得た所見はム。形狀（諸方向への笑出，副屌，不

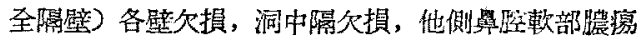

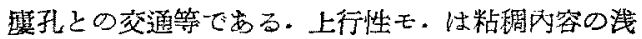
い洞で上行世始事があり, 又上行性モ。上下行性 モが接触すると混合して下行するから必ず耐者時老 置いて炷入し，両者の閻に內签液が介在して三畨に なる楞にせねばならぬ・

X VIII

76. 懪性副竟照炎に於ける血中及び 粘膜內「ヒスタミン」量より見 たる組織像に就いて

$$
\begin{aligned}
& \text { 松田豪一 高須照男 (演) } \\
& \text { 中村月子 (名市大) }
\end{aligned}
$$

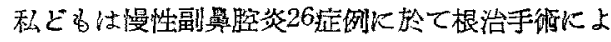
り得た上颚洞粘膜定材料としてその粘膜內「ヒスタ ミン」量ととるに手征前血中「七スタミン」量をる 定量し，それが同粘膜より作成した組織標本に上る 組織所見と如何なる関係にあるか在㮝傠して次の成 